\title{
The Sociolinguistic Status Quo of the English Language Departments in Jordan: A Language Planning Perspective
}

\author{
Dima Maithalouni, Fawwaz Al-Abed Al-Haq, Mujdey Abudalbuh * \\ Department of English, Yarmouk University, Jordan
}

Received on: 30-1-2020

Accepted on: 2-9-2020

\begin{abstract}
This study aims at investigating the missions and visions of the English departments in Jordan from a language planning perspective. To this end, a questionnaire was developed following Tollefson's model (1989) with a modified version of the instruments used in the previous studies conducted by Al-Abed AlHaq and Smadi (1996) and Abu Dalbouh (2002). The items of the questionnaire targeted the five main elements of the study: the adequacy of the current objectives of the English departments, the adequacy of the English language courses, the sociolinguistic relation between students and English language, the English department policies, and the potential stakeholders involved in formulating a language planning policy. The questionnaire was distributed to 150 English language majors in three public universities in Jordan. The study concluded that the objectives of the English language departments are theoretical rather than practical, revealing a mismatch between the objectives and plans on the one hand and the outcomes of these departments, on the other. The findings also indicated that the objectives of the English departments are too ambitious and far beyond the needs of the students and the needs of the market; thus, a reconsideration of the policy followed by these departments is urgently needed.
\end{abstract}

Keywords: Language planning and policy, Sociolinguistics, English departments, Missions, Visions, Objectives.

\section{Introduction}

Over the last few decades, studying English language and literature has witnessed a high demand by Jordanian students as well as students from other nationalities who study at Jordanian Universities. The number of students registered at the English language departments in Jordanian universities is increasing dramatically every year. This increase necessitates introducing an efficient language planning policy (LPP) with high quality standards to be the basis for organizing the process of teaching English at Jordanian universities. However, the rapid development of English as a discipline has led to new challenges where it became necessary to review these goals to make them suit the current situation, and to review the principle of language planning (LP) and its relation to the visions and missions set by each English language department.

There have been several definitions of language planning and policy by several scholars since the discipline first appeared. For example, Kaplan and Baldauf $(1997,3)$ explain that "language planning is a

\footnotetext{
๑ 2021 JJMLL Publishers/Yarmouk University. All Rights Reserved,

* Doi: https://doi.org/ 10.47012/jjmll.13.2.2

* Corresponding Author: majdi.a@yu.edu.jo
} 
body of ideas, laws and regulations (language policy), change rules, beliefs, and practices intended to achieve a planned change (or to stop change from happening) in the language use in one or more communities". Also, Al-Abed Al-Haq (2009, 85) defines Language planning as "a branch of sociolinguistics that deals with the study of the relationship of language to society and the extent of their influence on each other". Al-Abed Al-Haq (2009) points out that language planning is concerned with the study of the problems facing the language, whether purely linguistic problems, such as vocabulary generation, modernization, the construction and unification of vocabulary, or non-linguistic problems affecting language and its use.

\subsection{Status of English in Jordan}

Previewing the status of the English language in Jordan is a necessity in order to investigate the language policy of the English language departments in the country. Drabseh $(2013,3)$ argues that "it is more difficult than one might believe to delineate clearly the relationship between society and language spread because past, more recent, and possible future events and changes play roles which are sometimes difficult to assess empirically". Moreover, Drabseh attributes the spread of English language in Jordan to the status of English as a language of wider communication (LWC) and to the policy adopted by decision makers.

Hamdan and Abu Hatab (2009) investigated the status of English language in Jordan as reflected in newspapers job advertisements and English language documents in the educational domain, which he describes as an important domain to trace the change of status of English. Harrison et al. $(1975,106)$ claimed that "the mastery of English is extremely important for a reasonably large segment of the Jordanian population". Harrison et al. focused on the impact of school study on English mastery, in addition to university students' tendency to specialize in English language major to get better jobs inside and outside Jordan.

\subsection{The implication of LP to the status of English in Jordan}

A strategic plan for the teaching and learning of English in Jordan begins with formulating macrogoals represented in political, ideological, and socioeconomic aspects combined with macro implementation policies at higher political and administrative levels. This should be followed with microgoals at the university and institutional level and the execution of these goals through actions at the level of English language departments.

Tollefson (1989) provided a model which was described as an overall perspective for the variables that affect language learning/teaching situation. Tollefson $(1989,25)$ stated that "the LP process constitutes a set of intermediate variables which in turn affect input, learner, learning and learned variables". Such a model can be applied to the status of English language in Jordan as the following: 
The Sociolinguistic Status Quo of the English Language Departments in Jordan:

A Language Planning Perspective

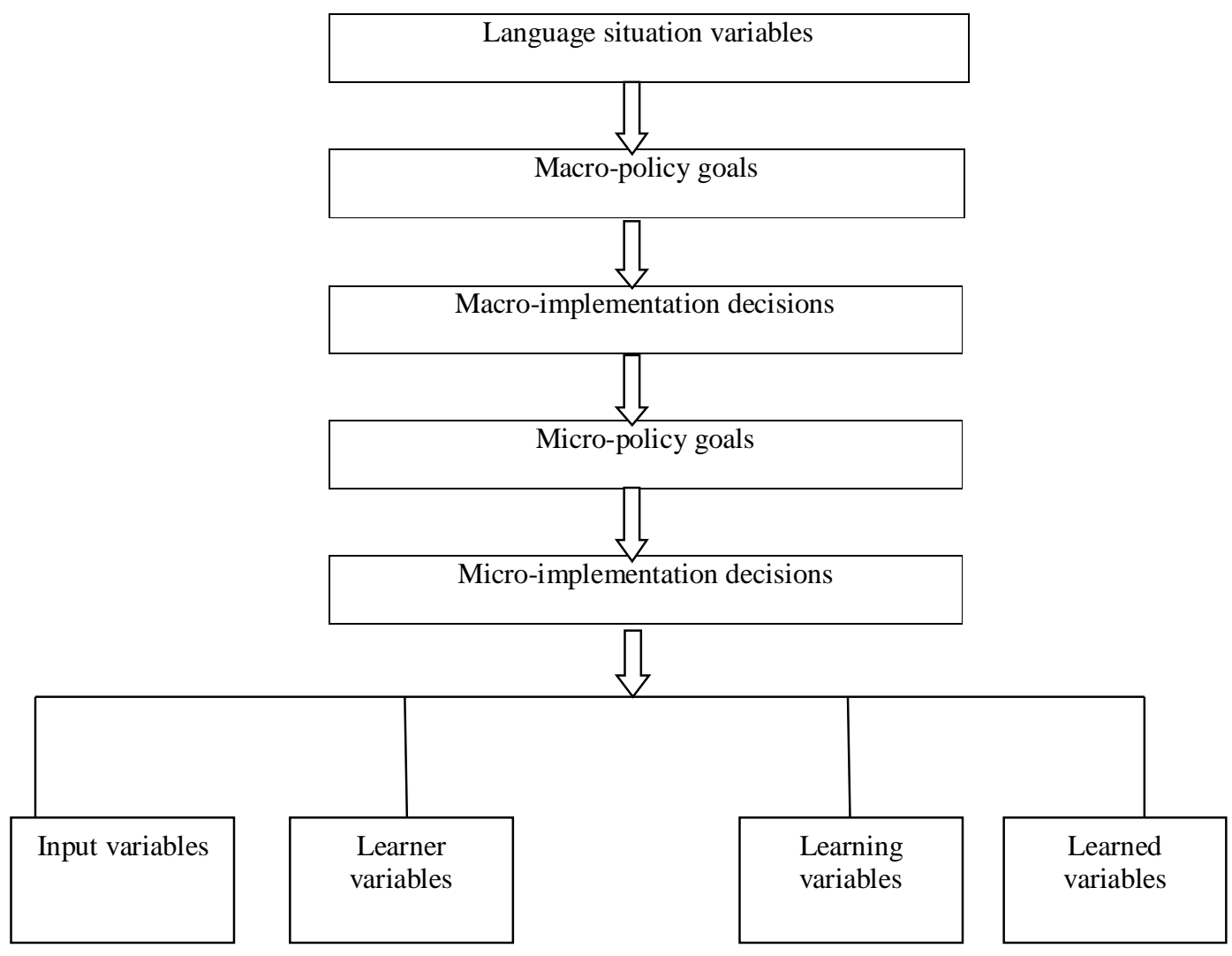

Figure 1: Tollefson's (1989) model for the role of LP in second language acquisition

\subsection{Background of the Study}

Due to the importance of language planning and its effect on the outcomes of English language departments, many studies have tackled this issue from different perspectives and it has been subject of deliberations and discussions of academic people interested in this critical area. Cooper $(1989,43)$ stated that "language planning refers to deliberate efforts to influence the behavior of others with respect to the acquisition, structure, or functional allocation of their language codes". Hao (2018) referred to the policy of language education as the policy related to the acquisition of language in formal education, which generally includes the regulations and documents of the governments at all levels, the regular work of the subordinates, and so on.

The current study is developed following Abu Dalbooh's (2002) study. In his study which targeted students of the English departments at six public Jordanian universities, Abu Dalbooh examined the English departments in Jordan regarding the clearness of their objectives and their appealing to the needs of the students, in addition to the role of the English departments in the Arab world. On the other hand, his study examined the attitudes of the students towards English language from many perspectives. The study devised a language planning policy model for Jordanian universities following Tollefson's model, due to the absence of a clear linguistic planning policy at the time. 
The main reason behind the current study is the continuous dissatisfaction among scholars regarding the performance of the English language departments in Jordan. It indicates the necessity to conduct new studies to utilize and develop what previous related studies have started with, and to examine the consideration of English language departments with regard to their objectives in order to keep up with the needs of the market. Besides, this study attempts to investigate the development of the English departments coinciding with the current situation.

\subsection{Statement of the Problem}

Most of the written objectives of the English departments at Jordanian Universities are to seek creativity and to contribute to the improvement of education and scientific research. But regardless of their written objectives, there are some doubts and questions regarding the plans and strategies followed by these English departments to turn out competent students that can use and teach English. Some raised doubts state that graduates of English departments are unqualified and do not have the capacity to teach or use language professionally after graduation due to language planning strategies adopted by these departments. Zughoul $(1985,24)$ explained that "although English language is used broadly in the Arab world, English departments have failed to produce linguistically competent graduates...it is proposed that English departments should teach English and provide an understanding of the culture rather than trying to acculturate Arab students into the English system as they have traditionally done".

This study attempts to identify the areas of weaknesses in language policy followed by the departments of English language at Jordanian universities and to provide solutions that contribute to developing different variables in the process of language teaching.

\subsection{Questions of the Study}

This study aims to highlight the missions and visions of the English language departments at Jordanian universities and their success in achieving them from a language planning perspective. The study aims to answer the following questions:

1) To what extent are the objectives of the English language departments clear and understandable by students and appealing to needs of the students and the market?

2) To what extent are the English language departments' courses adequate to meet the needs of the students regionally and internationally?

3) To what extent do the attitudes of students toward the English language affect their performance in learning the language?

4) To what extent is there an adequate language policy followed by the English departments in Jordanian universities?

5) Who is responsible for formulating an efficient language planning policy for the English departments at the Jordanian universities? 
The Sociolinguistic Status Quo of the English Language Departments in Jordan:

A Language Planning Perspective

\subsection{Significance of the Study}

The researcher has adopted the method of AbuDalbooh (2002) and has extended and reapplied the instrument to include Yarmouk University, University of Jordan and Al-Balqa' Applied University following Tollefson's model of language planning in second language learning and acquisition. Hence, the current study provides a modern and more comprehensive view of the linguistic status quo in the English departments in Jordan, taking into consideration the impact of sociolinguistic factors and attitudes of the respondents on the efficiency of students' language learning and university outcome.

\section{Theoretical Background and Review of Related Literature}

Several studies were conducted by different researchers considering the quality of performance of various university departments in Jordan, but only a few have focused on English departments in particular. Studies conducted in the field of language planning regarding education and English departments in particular are very limited. On the other hand, many contributions were presented in the related theoretical perspective.

\subsection{Theoretical background}

Fishman (1972) referred to a set of factors that include who speaks what language varieties, to whom and for what purpose as language situation variables. In the context of language planning, Fishman (1974, 79) stated that language planning is "the organized pursuit of solutions to language problems typically at the national level".

Abuhamdia (1984) discussed the problems encountered by the English departments in the Arab world as symptomatic to their failure, in addition to ignoring these departments to two main elements. The first element is the socio-linguistic position of English language as well as the assumed level of linguistic knowledge of students entering these departments. The second element is the relationship between the goals and programs of these departments on the one hand, and the needs of the community on the other. Abuhamdia concluded that current efforts to resolve these issues will remain fruitless until the reasons for the problems are properly realized.

Fishman (1987) viewed language planning as the authoritative allocation of resources to the attainment of language status and corpus goals, whether in connection with new functions that are aspired to or in connection with old functions that need to be discharged more adequately. In this sense, Bader (1992) agreed with many other scholars who criticized the teaching methods of English departments and calls for a "mandatory" change or a "shift" in the curricula of English in higher education in the Arab countries. After reviewing literature courses in some English departments, he criticizes those who defend the literature courses which he describes as the bulk of courses, and confirms that these departments are not as satisfactory as they claim.

Similarly, Obeidat (1997) criticized the superiority of literature courses at the expense of linguistic courses in Arab universities and condemned that the predominance of literature in the curricula is one of the main causes that lead to the failure of English departments and thus disables students to achieve their 
goals and ambitions. Accordingly, the main purpose of teaching English literature to students of English departments in the Arab world is "glossing vocabulary items".

A model was presented by Al-Abed Al-Haq (2011) who suggested a strategic plan to be followed for teaching and learning of foreign languages in the Arab countries. The model consisted of six levels beginning with the actions at department level, strategies at university level, micro-goals at university and institutional levels, planning assumptions, core values, and ending with macro-goals for promoting foreign languages.

\subsection{Empirical studies}

The empirical studies include studies at the international level, studies at the Arab level, and Jordanian studies. Butler and lino (2004) studied the changes in policy regarding English education in Japan after the proposition of "Action Plan to Cultivate Japanese with English Abilities" in an attempt to give a greater autonomy to teachers and local governments and thus to improve English education by enabling them to become active participants in the development of language education policies rather than simply being passive consumers of such policies. The study highlights the importance of learning English by the Japanese people to raise their ability to communicate with foreigners and thus to boost Japan's position in the international economic and political arena. The authors mention the impact of University examination on English in Japan by which it tends to heavily emphasize reading and the grammatical aspects of English and gives little attention to oral skills.

Denis (2010) discussed the impact of globalization on higher education in developing countries like Uganda, and contends on its huge influence on the international nature of universities to meet global needs and to stratify with the international practice. The study concluded that a large proportion of students believe that the postgraduate curriculum must be modified to suit the requirements of the labor market and that universities should provide technically useful knowledge competencies to address the problem of theoretical learning.

Zughoul (1987) conducted a study to examine the importance of intensifying the linguistics courses in the English departments of the Arab world. His study included the universities of Baghdad, Iraq; Damascus, Syria; Kuwait, Kuwait; Yarmouk, Jordan; Amman, Jordan and two other American universities in the Middle East. He concluded that the curricula of the Arab universities which he studied focused on literature courses rather than linguistic courses which he described as "the weakest of all" and "underrepresented". Furthermore, he pointed out that this is a major reason of many others which led to the failure of the English language departments in Arab universities to meet the requirements of the society.

Al-Abed Al-Haq and Smadi (1996) examined the use of English in Saudi Arabia from a different perspective which focused on its impact on the students' attitudes toward their religious commitment and westernization based on a fear among Saudi students. The study included students representing all the universities in the KSA and the results showed that the use of English does not corrupt their religious commitment and does not have any impact on the participants' attitudes nor makes them westernized. 
The Sociolinguistic Status Quo of the English Language Departments in Jordan:

A Language Planning Perspective

This study indicates a reflection of the attitude and the sociolinguistic relation between students and English language.

Zughoul and Hussein (1985) examined the use of English language in Yarmouk University. Separate questionnaires were distributed to 1147 students and 90 faculty members. The questionnaires investigated three major issues: the extent of English language use at the university; perception of the students' language abilities; and perception of English language needs. The results showed the widespread use of English in most educational settings except for class discussions and student questions in lectures. However, students and faculty members agreed on the importance of specific skills like listening, but their opinions diverged in many different areas. The authors argued that students tend to overestimate their abilities in different language skills, while a more realistic estimate is reflected in the responses of the faculty.

AbuDalbooh (2002) recommended a language planning policy model for Jordanian universities as there was not a clear linguistic planning policy at the time. The researcher used a survey to investigate to what extent Jordanian universities have a language planning policy. The questionnaire was distributed to 300 English major students in six public Jordanian universities including Yarmouk University and the University of Jordan. The study concluded that English language departments in some Jordanian universities did not have a language planning policy. Accordingly, he introduced a language planning policy model following Tollefson's model for English departments in Jordan.

Muhaisen and Al-Abed Al-Haq (2007) conducted a study to find out which aspect of language learning causes the greatest amount of anxiety for student, in addition to examine the relationship between language anxiety and students performance in second language learning and from both teachers' and learners' points of view. The authors used a questionnaire and socio linguistics interview method with second secondary students in Amman including each aspect of English learning. The study concluded to a moderate degree of language anxiety experienced by second secondary students in learning listening skills, speaking, reading and grammar, while the degree of language students' anxiety while learning writing is high with taking into account the statistical differences between males and females in their anxiety in learning of specific aspects of language learning.

In conclusion, many researchers investigated the English education process locally and internationally, and many of them discussed the failure of English departments to meet the expected outcomes, in higher education in particular. However, very few discussed the actual reasons behind this failure. Rather, most of the studies tackled this issue theoretically and relying for the most part on one factor from a narrow point of view. A comprehensive study that covers all aspects involved in formulating the policy of English departments is urgently needed. Indeed, investigating the English language departments from language planning perspective provides a comprehensive and practical approach through which impeding factors can be discussed both theoretically and practically, solutions may be suggested, and outcomes can be set in an effective language policy and language planning model that meets all the requirements and needs of all parties involved in the English education process. 


\section{Method and Procedure}

The current study followed a descriptive and analytical methodology in the form of a general analysis of the current objectives of the English language departments and statistical analysis of students' responses to the questionnaire. The researcher has chosen a survey research design because it best serves the purposes and the questions of the study. The survey focused on several aspects that have a direct or indirect impact on the results of the research, starting with the policy of the departments of English language and the compatibility of this policy with its outputs, in addition to the students themselves and the extent of their knowledge of this policy. A questionnaire consisting of 32 items was distributed randomly among the population of the study. The researcher collected the questionnaires and analyzed them and the results were compared to previous studies in order to answer the questions of the study.

\subsection{Participants of the study}

The participants of this study were 150 students from the English language departments in three Jordanian public universities which are Yarmouk University, University of Jordan and Al-Balqa' Applied University, with 50 students from each university. . The universities were chosen for logistic purposes and the participants were English language students with different backgrounds and attitudes of both genders.. Most of the students were third and fourth year students selected for their ability to evaluate the policies of their departments rather than first year students as shown in Table 1.

Table 1: Distribution of the Sample of the Study.

\begin{tabular}{|c|c|c|c|}
\hline Variable & Values & Numbers & Percent\% \\
\hline \multirow{5}{*}{ University } & Yarmouk University & 50 & $33.3 \%$ \\
\hline & University of Jordan & 50 & $33.3 \%$ \\
\hline & Al-Balqa' Applied University & 50 & $33.3 \%$ \\
\hline & Missing & -- & -- \\
\hline & Total & 150 & $100 \%$ \\
\hline \multirow{4}{*}{ Place of residence } & Urban & 70 & $46.7 \%$ \\
\hline & Rural & 39 & $26 \%$ \\
\hline & Missing & 41 & $27.3 \%$ \\
\hline & Total & 150 & $100 \%$ \\
\hline \multirow{4}{*}{ Gender } & Male & 12 & $8 \%$ \\
\hline & Female & 111 & $74 \%$ \\
\hline & Missing & 27 & $18 \%$ \\
\hline & Total & 150 & $100 \%$ \\
\hline \multirow{5}{*}{ Father education } & Education & 130 & $86.7 \%$ \\
\hline & No - education & 2 & $1.3 \%$ \\
\hline & Other & 8 & $5.3 \%$ \\
\hline & Missing & 10 & $6.7 \%$ \\
\hline & Total & 150 & $100 \%$ \\
\hline \multirow{5}{*}{ Mother education } & Education & 134 & $89.3 \%$ \\
\hline & No - education & -- & -- \\
\hline & Other & 6 & $4 \%$ \\
\hline & Missing & 10 & $6.7 \%$ \\
\hline & Total & 150 & $100 \%$ \\
\hline \multirow{5}{*}{ Attitude } & Liberal & 14 & $9.3 \%$ \\
\hline & Conservative & 86 & $57.3 \%$ \\
\hline & Religious & 14 & $9.3 \%$ \\
\hline & Missing & 36 & $24 \%$ \\
\hline & Total & 150 & $100 \%$ \\
\hline
\end{tabular}


The Sociolinguistic Status Quo of the English Language Departments in Jordan:

A Language Planning Perspective

Table 1 presents the sample of the study in terms of six variables: university, place of residence (rural / urban), gender, father education, mother education, and attitude (liberal, conservative, religious). Table 2 shows the participants' degree of understanding of the questionnaire items measured in terms of their responses to item (32) in the questionnaire ( I fully understood the previous questions and responded accordingly"), with " 5 " being the highest degree of understanding and " 1 " being the lowest degree of understanding.

Table 2: Students' level of Understanding of the Questionnaire

\begin{tabular}{lll}
\hline University & Mean & Level \\
\hline All sample & 4.23 & High \\
Yarmouk University & $\mathbf{4 . 4 6}$ & High \\
University of Jordan & 3.88 & High \\
Al-Balqa' Applied University & 4.34 & High \\
\hline
\end{tabular}

The mean value for the entire sample showed high level (85\%) of understanding of the instrument items as the mean value was (4.23 out of 5.00). Moreover, the students of Yarmouk University reported the highest level of agreement among the sample as the mean value was (4.46), whereas students of AlBalqa' Applied University reported the second high Mean value as recorded (4.34) and finally students of the University of Jordan reported the lowest level of agreement for understanding instrument items with Mean value (3.88). Following the high agreement level for the reliability item, it is evident that instrument items are well understood by the students, which adds to the credibility of the study.

\subsection{Instrument of the study}

The survey of the study included 32 items following Tollefson's (1989) model. The questionnaire was developed by the researcher with a modification of a survey in a previous study conducted by AlAbed Al-Haq and Smadi (1996) and Abu Dalbouh (2002). The items of the questionnaire were developed accurately to target five main domains of the study: the adequacy of the current objectives of the English departments (items 1-10,13,14), the adequacy of the English language courses (items 16-18), the attitudes of students towards English language (items 11,12,14), the English department policies (items 19-25), and the responsible actors for formulating a language planning policy (items 26-29). The students responded to the items of the questionnaire on a five-interval Liker scale ranging from 1 to 5 in the following order: strongly disagree (SD), disagree (D), uncertain (U), agree (A), and strongly agree (SA). The questionnaire was developed and distributed among students in Arabic to ensure full comprehension of the components of the questionnaire and to get more accurate and reliable results. An English version of the questionnaire is provided for readers' reference (see Appendix B).

\subsection{Data analysis}

The data of the questionnaire were statistically analyzed using the Statistical Package for the Social Sciences (SPSS) program. The tests carried out in the analysis were One-Way ANOVA and T-Test. The Mean and Standard deviation were calculated for each variable. The values were also calculated for the 
five domains of the study: the adequacy of the objectives of the English language departments, the adequacy of the English language departments' courses, the adequacy of the policies of the English language departments, the attitudes of students towards the English language, and the responsibility of formulating a language policy. The hypotheses of this study were checked in these five domains to indicate significant differences attributed to the six variables: university, gender, place of residence, mother's level of education, father's level of education and attitude.

\subsection{Reliability}

Reliability represents instrument power to provide same adequate results when reused in similar settings. The reliability of the instrument in this study was confirmed through the values of Cronbach $\alpha$ as (Sekaran and Bougie, 2016) suggested that the values of Cronbach $\alpha$ should be (.60) or higher for better reliability. The statistical analysis shows that the Cronbach alpha for internal consistency of this study is 0.755. Statistically, this value indicates high reliability regarding the students' responses to the questionnaire.

\section{Results and Discussion}

This section introduces the results of the study based on the statistical analysis of students' responses to the questionnaire. The students' responses to the questionnaire in the three universities were analyzed as a single unit except for when it was necessary to deal with them separately. The questionnaire was divided and analyzed into five parts where each part represents one dimension. The dimensions and the results are presented in Tables 3-12.

\subsection{Statistical analysis of students' responses to the questionnaire}

The first dimension in this study examines the adequacy of the objectives of the English language departments and aims at providing an answer for the following question: To what extent are the objectives of the English language departments clear and understandable by students and appealing to the needs of the students and the market?

Table 3: The adequacy of the objectives of the English language departments Ranked in a descending order $(\mathrm{N}=150)$

\begin{tabular}{llllll}
\hline Rank & $\#$ & \multicolumn{1}{c}{ Item } & Mean & Std. & Level \\
\hline $\mathbf{1}$ & $\mathbf{1 3}$ & $\begin{array}{l}\text { The objectives of the English department are theoretical } \\
\text { and not practical }\end{array}$ & 3.62 & 1.20 & High \\
$\mathbf{2}$ & $\mathbf{1}$ & $\begin{array}{l}\text { The objectives of the English department in which I study } \\
\text { are clear }\end{array}$ & 3.42 & 1.08 & High \\
$\mathbf{3}$ & $\mathbf{6}$ & $\begin{array}{l}\text { The objectives of the English Department correspond to } \\
\text { the local market } \\
\text { The objectives of the English Department in which I }\end{array}$ & 2.83 & 1.08 & Moderate \\
$\mathbf{5}$ & $\mathbf{3}$ & $\begin{array}{l}\text { Then take the needs of the market into consideration } \\
\text { The objectives of the English department in which I study } \\
\text { take the needs of the students into consideration }\end{array}$ & 2.68 & 1.12 & Moderate \\
$\mathbf{6}$ & $\mathbf{2}$ & $\begin{array}{l}\text { The objectives of the English department in which I study } \\
\text { do not need reconsideration }\end{array}$ & 2.31 & 1.31 & Moderate \\
\hline Total Mean & & $\mathbf{2 . 9 2}$ & Moderate \\
\hline
\end{tabular}


The Sociolinguistic Status Quo of the English Language Departments in Jordan:

A Language Planning Perspective

The first group of items (Table 3) examines the adequacy of the current objectives of the English departments in terms of their clearness and understand ability as well as their ability to meet the desired needs of the students. Overall, the participants' response to these items was moderate with a mean value of 2.92 .

About half of the students said that the English departments do not take the needs of the students into consideration (Item 2). Also, about half of the student sample (44\% and 46\%) believe that the English departments do not correspond to the needs of the market nor take do they take the market needs into consideration. Similarly, more than half of the students (54\%) said that the objectives of the English departments in which they study need to be reconsidered (Item 4). This result sets the objectives of the current language departments in the task of redrafting these objectives to meet the requirements of the current situation and to meet the needs of students and the needs of the market, in addition to all parties that the English language departments have a direct or indirect impact on them. The students' response to Item 13 indicates an $73 \%$ agreement among the students that the objectives of the English departments are theoretical rather than practical.

The overall low-to-moderate values of the previous items make it important to reconsider the objectives of the English departments in terms of their capability to meet the desired goals of its students and to achieve their needs after university. On the other hand, the response of students shows unexpected agreement with most of the items regarding the adequacy of the objectives of the English departments. Such a result raises the question of the basis on which students assist and perceive these objectives compared to the students' dissatisfaction regarding other aspects as shown in other dimensions later of the study.

As shown in Table 4, the second dimension of this study explores the adequacy of the English departments' courses and aims at answering the following question: To what extent are the English departments' courses adequate to meet the needs of the students regionally and internationally? To answer the question, 7 items were included in the questionnaire asking the students to assess the adequacy of the provided courses by their departments. Descriptive statistics for courses adequacy items were provided through mean and standard deviation as shown in the following table.

Table 4: The adequacy of English departments' courses Ranked in a descending order $(\mathrm{N}=150)$.

\begin{tabular}{|c|c|c|c|c|c|}
\hline Rank & \# & Item & Mean & Std. & Level \\
\hline 1 & 31 & $\begin{array}{l}\text { English language departments must be transformed into } \\
\text { application departments offering specialized language courses } \\
\text { in the fields of English for business, tourism and so on }\end{array}$ & 4.32 & .93 & High \\
\hline 2 & 30 & $\begin{array}{l}\text { English language departments should focus more on language } \\
\text { skills courses (such as listening, speaking and writing) at the } \\
\text { expense of other courses }\end{array}$ & 4.22 & 1.10 & High \\
\hline 3 & 18 & There is a practical benefit of linguistics courses & 3.77 & 1.04 & High \\
\hline 4 & 7 & $\begin{array}{l}\text { The current English language courses correspond to the } \\
\text { objectives of the department }\end{array}$ & 3.27 & 1.07 & Moderate \\
\hline 5 & 17 & There is a practical benefit of literature courses & 3.22 & 1.23 & Moderate \\
\hline 6 & 15 & The current English courses meet my current needs & 3.15 & 1.12 & Moderate \\
\hline 7 & 16 & $\begin{array}{l}\text { The current English courses are sufficient to graduate } \\
\text { competent students }\end{array}$ & 2.81 & 1.25 & Moderate \\
\hline \multicolumn{3}{|c|}{ Total Mean } & 3.60 & & High \\
\hline
\end{tabular}




\section{Maithalouni, Al-Abed Al-Haq, Abudalbuh}

Following students' assessments of the adequacy of the provided courses by their departments, the overall rate of agreement with the proposed items was moderately high (72\%) with a mean value of 3.53. The students' agreement was moderate (66\%) with the statement that the current English language courses correspond to the objectives of the departments and to the current needs of the students. On the other hand, about half of the students (44\%) said that the current English courses are insufficient to graduate competent students (Item16). The students' response to Item 17 shows a moderate level of agreement $(64 \%)$ with the existence of a practical benefit of literature courses and a high level of agreement $(75 \%)$ that there is a true practical benefit of linguistics courses. Such a result is in line with the arguments of some scholars who stressed the importance of the linguistics courses like Ibrahim (1983), Bader (1990) and Saleh (1989).

Following the results shown in the previous table for items 30 and 31, students highly agree (84\% and $86 \%$, respectively) that the English language departments should focus more on language skills courses (such as listening, speaking and writing) at the expense of other courses. They also agree that English language departments must be transformed into practical departments offering specialized language courses in the fields of English for business, tourism and so on (i.e., English for Specific Purposes (ESP) courses). In this regard, Hutchinson et al. $(1987,19)$ stated that "ESP is an approach to language teaching in which all decisions as to content and method are based on the learner's reason for learning".

In general, the overall level of the course adequacy dimension indicates that the provided courses do not provide students with all required outcomes that would meet their needs sufficiently. In this regard, Ibrahim $(1983,23)$ argued that "although most of our students are deficient in the basic language skills when they join the department, we have not yet succeeded in offering them an integrated set of language courses to improve their proficiency significantly but nothing is offered to help them become better and more fluent speakers of English".

The third dimension in this study examines the attitudes of students toward the English language and aims at answering the following question: To what extent do the attitudes of students toward the English language affect their performance in learning the language?

Table 5: The attitudes of students towards the English language Ranked in a descending order $(\mathrm{N}=150)$.

\begin{tabular}{|c|c|c|c|c|c|c|}
\hline Rank & $\#$ & Item & Mean & Std. & $\%$ & Level \\
\hline 1 & 11 & $\begin{array}{l}\text { The social background of the student (such like } \\
\text { the surrounding environment) affects his ability to } \\
\text { learn English }\end{array}$ & 4.27 & 1.04 & $85 \%$ & High \\
\hline 2 & 10 & $\begin{array}{l}\text { I study English for specific goals like traveling } \\
\text { abroad and communicating with the outside world }\end{array}$ & 4.09 & 1.08 & $82 \%$ & High \\
\hline 3 & 9 & I study English with no specific goal* & 4.05 & 1.07 & $81 \%$ & High \\
\hline 4 & 8 & $\begin{array}{l}\text { I study English to achieve a specific physical and } \\
\text { moral goal }\end{array}$ & 3.99 & 1.12 & $80 \%$ & High \\
\hline 5 & 12 & $\begin{array}{l}\text { There is a relationship between the academic } \\
\text { performance of the students in the English } \\
\text { language and their study of English }\end{array}$ & 3.97 & 1.30 & $79 \%$ & High \\
\hline 6 & 14 & $\begin{array}{l}\text { There is a psychological barrier between the } \\
\text { student and English }\end{array}$ & 3.75 & 1.05 & $75 \%$ & High \\
\hline \multicolumn{3}{|c|}{ Total Mean } & 3.60 & & $80 \%$ & High \\
\hline
\end{tabular}

* Negative item, therefore, answers were reversed 
The Sociolinguistic Status Quo of the English Language Departments in Jordan:

A Language Planning Perspective

Overall, there was $80 \%$ agreement with the proposed items with a mean value of 3.60 as shown in Table 5. As such, there was $85 \%$ agreement with the idea that students study English to achieve specific goals which is mostly getting good jobs. Besides, about $82 \%$ of the students said that they study English for specific reasons like travelling abroad, which is probably to look for better work opportunities as they responded with a high value for items (8-10). Such a result is in line with Harrison et al.'s (1975) report which attributed the reason behind studying English in Jordan for getting a better chance of studying and working abroad or in Jordan.

Also, there was an $85 \%$ agreement with the statement about the importance of the students' social background and its effect on their ability to learn English (Item11). It is also obvious that there is a relationship between the academic performance of the students in the English language and the students' study of English (Item12), and three quarters of the sample confirmed the existence of a psychological barrier between them and the English language (Item 14).

All items proposed previously were in high level of agreement with no homogeneity across sample answers. This high level of agreement emphasizes the need to take the social and psychological attitudes of students into account as they seem to substantially influence students' potential for learning the English language. Also, such a result points out to a critical issue that needs to be considered when formulating language planning policies and courses to override possible barriers that may stem from this relation.

Table 6: The adequacy of the policies of the English departments Items Ranked in a descending order $(\mathrm{N}=150)$.

\begin{tabular}{|c|c|c|c|c|c|}
\hline Rank & \# & Item & Mean & Std. & Level \\
\hline 1 & 23 & $\begin{array}{l}\text { A language planning policy should take the problems that } \\
\text { face the student and the department into consideration }\end{array}$ & 4.37 & .83 & High \\
\hline 2 & 24 & $\begin{array}{l}\text { The existence of a unified plan and policy for the English } \\
\text { language departments contributes to the greatest benefit }\end{array}$ & 4.21 & .96 & High \\
\hline 3 & 19 & $\begin{array}{l}\text { There should be specific qualifications for students to be } \\
\text { accepted to the English department }\end{array}$ & 3.93 & 1.14 & High \\
\hline 4 & 22 & $\begin{array}{l}\text { There is a goal behind establishing the English } \\
\text { department in Jordan }\end{array}$ & 3.73 & 1.10 & High \\
\hline 5 & 21 & $\begin{array}{l}\text { There should be an admission exam for the English } \\
\text { department }\end{array}$ & 3.71 & 1.36 & High \\
\hline 6 & 25 & $\begin{array}{l}\text { There is a difference between the goals and the plans of } \\
\text { the English departments in Jordanian Universities }\end{array}$ & 3.61 & 1.00 & High \\
\hline 7 & 5 & $\begin{array}{l}\text { The department's current language policy serves the } \\
\text { current objectives of the department }\end{array}$ & 3.15 & 1.06 & Moderate \\
\hline 8 & 20 & $\begin{array}{l}\text { The policy of examination in the English department is } \\
\text { successful }\end{array}$ & 2.78 & 1.23 & Moderate \\
\hline \multicolumn{3}{|c|}{ Total Mean } & 3.68 & & High \\
\hline
\end{tabular}

Table 6 above shows the items of the fourth dimension in this study which addresses the policies of the English departments in Jordan in terms of their language planning policy, admission, and examination. These items aim at answering the following question: to what extent is there an adequate language policy followed by the departments of English in Jordanian universities?

For items 19 and 21, there was a moderately high agreement (79\% and 74\%, respectively) among the students that there should be an admission exam in addition to specific qualifications for students to be 
admitted to the English departments. Also, students highly believe (84\%) that the existence of a unified plan and policy for the English language departments contributes to the greatest benefit. However, the students seem unsatisfied about the examination policy followed by their English departments for they responded to item (20) with an overall moderate level of 2.78 showing a $56 \%$ endorsement of the examination policy. In this regard, Abu Dalbooh $(2002,63)$ claimed that "the students tend always to complain about examination, sometimes unreasonably".

Moreover, there was a moderately high agreement (72\%) with regard to the existence of a mismatch between the goals and the plans of the English departments in the Jordanian Universities (Item 25). Such a result supports the validity of some students' complaints of the existence of gaps between the students' desired goals and what they are exposed to in university in terms of teaching and course offerings.

The fifth dimension in this study deals with the responsibility of formulating a language planning policy to be followed in the English language departments in Jordan, or as Cooper (1989) calls it 'the actors in policy formulation'. This dimension aims at answering the following question: who is responsible for formulating an efficient language planning policy for English departments at Jordanian universities?

To provide answer to this question, four items were provided in the questionnaire and students' responses to the items were analyzed as shown in Table 7 below.

Table 7: The responsibility of formulating a language planning policy items Ranked in a descending order $(\mathrm{N}=150)$.

\begin{tabular}{|c|c|c|c|c|c|}
\hline Rank & \# & Item & Mean & Std. & Level \\
\hline 1 & 26 & $\begin{array}{l}\text { The responsibility of formulating a language planning } \\
\text { policy for the English departments lies on the departments } \\
\text { themselves }\end{array}$ & 3.87 & .99 & High \\
\hline 2 & 29 & $\begin{array}{l}\text { The formulation of a language planning policy for the } \\
\text { English departments needs a collaborative political, social, } \\
\text { economic, educational, and academic effort }\end{array}$ & 3.82 & .97 & High \\
\hline 3 & 27 & $\begin{array}{l}\text { The responsibility of formulating a language planning } \\
\text { policy for the English departments lies on the dean councils } \\
\text { as well as the faculty councils }\end{array}$ & 3.52 & 1.12 & High \\
\hline 4 & 28 & $\begin{array}{l}\text { The responsibility of formulating a language planning } \\
\text { policy for the English departments lies on the political } \\
\text { decision-maker }\end{array}$ & 3.19 & 1.14 & Moderate \\
\hline \multicolumn{3}{|l|}{ Total } & 3.60 & & High \\
\hline
\end{tabular}

The overall response of students to this item group showed a relatively high agreement rate with a Mean value of 3.60. The students' response to Item 26 indicates that they strongly believe $(76 \%$ agreement rate) that the responsibility of formulating a language planning policy lies on the English department themselves. In comparison, the students seem to believe that the dean councils and the faculty councils come second after the English departments with regard to the responsibility of formulating a LP policy as their agreement rate about the involvement of such councils was $70 \%$.However, the students believe the least that the responsibility of formulating a language planning policy should be claimed by political decision makers.

In light of the students' responses to the previous items, the English departments themselves are considered the first and primary decision maker. This can be explained by the fact that students perceive 
The Sociolinguistic Status Quo of the English Language Departments in Jordan:

A Language Planning Perspective

the English language departments as the window that overlooks their aspirations and future goals by providing appropriate courses and making them ready for the market needs and post-graduation requirements. The students' agreement that the formulation of a language planning policy for the English departments needs a collaborative political, social, economic, educational, and academic effortis consistent with Rubin and Jernudd's (1971, xvi) statement that "language planning requires the mobilization of a great variety of disciplines because it implies the channeling of problems and values to and through some decision-making administrative structure. Moreover, the formulation of the policy of the English departments needs a collaborative effort that cannot be interpreted by an individual party, but each party is acting in accordance with its limited power".

\subsection{Testing the Hypotheses}

Four hypotheses were set in the beginning of the study:

1) There will be an overall dissatisfaction with the objectives and adequacy of course offerings among the students of English language.

2) There will be a strong correlation between the attitudes of students toward the English language and their English language learning outcomes.

3) Students will not be able to identify a clearly-formulated language planning policy in their English language departments.

4) The students' responses will vary depending on their attitude and university, but not in terms of gender, place of residence, or parents' level of education.

To test the hypotheses a One-Way Analysis of Variance (ANOVA) Test was conducted and post-test Scheffe in the case of significant differences to determine the source of differences. The analysis was carried out for the effect of five variables: university (Table 8), place of residence (Table 9), gender (Table 10), father and mother education (Table 11) and attitudes (Table 12) and the results are presented in the following tables.

Table 8: ANOVA analysis of the influence of university variable on the five domains

\begin{tabular}{|c|c|c|c|c|c|c|c|c|c|}
\hline \multirow[t]{2}{*}{ Dependent variable } & \multicolumn{2}{|c|}{$\begin{array}{l}\text { Yarmouk } \\
\text { University }\end{array}$} & \multicolumn{2}{|c|}{$\begin{array}{l}\text { University of } \\
\text { Jordan }\end{array}$} & \multicolumn{2}{|c|}{$\begin{array}{l}\text { Al-Balqa } \\
\text { Applied }\end{array}$} & \multirow[t]{2}{*}{$\begin{array}{l}\mathrm{F} \\
\text { value }\end{array}$} & \multirow[t]{2}{*}{ Sig. } & \multirow[t]{2}{*}{ Sig. Group } \\
\hline & Mean & Std. & Mean & Std. & Mean & Std. & & & \\
\hline Department policies & 3.62 & .59 & 3.58 & .54 & 3.85 & .43 & 3.706 & $\begin{array}{l}.027 \\
*\end{array}$ & Al-Balqa \\
\hline $\begin{array}{l}\text { Department } \\
\text { objectives }\end{array}$ & 2.81 & .64 & 2.86 & .69 & 3.10 & .54 & 3.066 & $\begin{array}{l}.050 \\
*\end{array}$ & Al-Balqa \\
\hline Department courses & 3.63 & .61 & 3.34 & .57 & 3.63 & .48 & 4.718 & $\begin{array}{l}.010 \\
*\end{array}$ & $\begin{array}{l}\text { Yarmouk } \\
\text { \& } \\
\text { Al-Balqa }\end{array}$ \\
\hline $\begin{array}{l}\text { Responsible actors } \\
\text { of formulating LPP }\end{array}$ & 3.52 & .70 & 3.61 & .82 & 3.60 & .60 & .456 & .635 & -- \\
\hline $\begin{array}{l}\text { Attitudes of } \\
\text { students toward } \\
\text { English }\end{array}$ & 4.160 & .61 & 3.87 & .61 & 4.01 & .54 & 2.883 & .059 & -- \\
\hline
\end{tabular}

Significant at level (0.05) 
Maithalouni, Al-Abed Al-Haq, Abudalbuh

Table 8 shows that there is a significant influence of the universities regarding their students' responses to the following domains: department objectives and policies in favor of Al-Balqa' Applied University. The table also shows a significant influence of the university regarding students' responses to the departments' courses domain in favor of both Yarmouk University and Al-Balqa' Applied University. Regarding the last two domains the formulation of language planning policy and students' attitudes, ANOVA analysis indicates that there is no significant difference between students' responses regarding the university variable.

Table 9: ANOVA analysis of the influence of place of residence on the five domains.

\begin{tabular}{|c|c|c|c|c|c|c|c|}
\hline \multirow{2}{*}{ Dependent variable } & \multicolumn{2}{|l|}{ Urban } & \multicolumn{2}{|l|}{ Rural } & \multirow[b]{2}{*}{$\mathbf{T}$ value } & \multirow[b]{2}{*}{ Sig. } & \multirow[b]{2}{*}{ Sig. Group } \\
\hline & Mean & Std. & Mean & Std. & & & \\
\hline Department policies & 3.61 & .51 & 3.85 & .47 & -2.412 & $.018^{*}$ & Rural \\
\hline Department objectives & 2.93 & .69 & 2.90 & .50 & .289 & .773 & -- \\
\hline Department courses & 3.50 & .58 & 3.75 & .48 & -2.323 & $.022 *$ & Rural \\
\hline $\begin{array}{l}\text { Responsible actors of } \\
\text { formulating LPP }\end{array}$ & 3.56 & .69 & 3.65 & .68 & -.675 & .501 & -- \\
\hline $\begin{array}{l}\text { Attitudes of students } \\
\text { toward English }\end{array}$ & 3.99 & .59 & 4.06 & .52 & -.607 & .545 & -- \\
\hline
\end{tabular}

Table 9 shows that there is a significant influence of students' responses to 2 domains due to their place of residence (rural/urban). The domains are: the department policies and the department courses. Post-test Schaffe was conducted and the result reported that the influence is in favor of rural place of residence over urban in both dimensions. However, regarding the objectives of the departments, the responsible actors and the attitudes of students toward English, Table 13 shows that there is no significant influence of students' responses to these three domains due to the respondents' place of residence

Table10: ANOVA analysis of the influence of gender on the five domains.

\begin{tabular}{|c|c|c|c|c|c|c|c|}
\hline \multirow{2}{*}{ Dependent variable } & \multicolumn{2}{|l|}{ Male } & \multicolumn{2}{|c|}{ Female } & \multirow[b]{2}{*}{ T value } & \multirow[b]{2}{*}{ Sig. } & \multirow[b]{2}{*}{ Sig. Group } \\
\hline & Mean & Std. & Mean & Std. & & & \\
\hline Department policies & 3.63 & .48 & 3.68 & .56 & -.318 & .751 & -- \\
\hline Department objectives & 2.83 & .63 & 2.94 & .62 & -.582 & .561 & -- \\
\hline Department courses & 3.42 & .48 & 3.56 & .60 & -.776 & .439 & -- \\
\hline $\begin{array}{l}\text { Responsible actors of } \\
\text { formulating a LPP }\end{array}$ & 3.93 & .64 & 3.51 & .70 & 1.986 & $.049 *$ & Male \\
\hline $\begin{array}{l}\text { Attitudes of students } \\
\text { toward English }\end{array}$ & 4.11 & .67 & 3.98 & .60 & .656 & .513 & -- \\
\hline
\end{tabular}

Table 10 shows that there is a significant influence of students' responses to the responsible actors of formulating a language policy domain due to their gender (male / female) in favor of males over females. The table shows no significant influence on students' responses due to the gender variable on the department policies domain, department objectives domain, department courses domain, and the attitudes of students towards English. 
The Sociolinguistic Status Quo of the English Language Departments in Jordan:

A Language Planning Perspective

Table11: ANOVA analysis of the influence of father and mother education on the five domains.

\begin{tabular}{lllll}
\hline \multirow{2}{*}{ Department variable } & \multicolumn{2}{l}{ Father education } & \multicolumn{2}{l}{ Mother education } \\
\cline { 2 - 5 } & F value & Sig. & F value & Sig. \\
\hline Department policies & .056 & .946 & .384 & .537 \\
Department objectives & .071 & .931 & .025 & .874 \\
Department courses & 1.371 & .257 & .000 & 1.00 \\
Responsible actors of formulating a & .340 & .712 & .176 & .675 \\
LPP & & & & .729 \\
Attitudes of students toward English & 1.127 & .327 & .120 &. \\
\hline
\end{tabular}

Significant at level (0.05)

Table 10 shows ANOVA results which reported that there is no statistical influence of students' responses to the adequacy of their department policies, adequacy of their department objectives, adequacy of their department courses, determining responsible actors for language policy formulation and attitudes of students towards English due to father education and mother education as two independent variables.

Table 12: ANOVA analysis of the influence of attitude variable on the five domains

\begin{tabular}{|c|c|c|c|c|c|c|c|c|c|c|c|}
\hline \multirow[b]{2}{*}{ Dependent variable } & \multicolumn{3}{|c|}{ Liberal } & \multicolumn{3}{|c|}{ Conservative } & \multicolumn{3}{|c|}{ Religious } & \multirow[b]{2}{*}{$\begin{array}{l}\mathbf{F} \\
\text { value }\end{array}$} & \multirow[b]{2}{*}{ Sig. } \\
\hline & $\mathbf{N}$ & Mean & Std. & $\mathbf{N}$ & Mean & Std. & $\mathbf{N}$ & Mean & Std. & & \\
\hline Department policies & 14 & 3.83 & .38 & 86 & 3.73 & .53 & 14 & 3.46 & .66 & 1.937 & .149 \\
\hline $\begin{array}{l}\text { Department } \\
\text { objectives }\end{array}$ & 14 & 2.78 & .76 & 86 & 2.96 & .57 & 14 & 2.82 & .85 & .716 & .491 \\
\hline Department courses & 14 & 3.36 & .58 & 86 & 3.58 & .58 & 14 & 3.59 & .77 & .778 & .462 \\
\hline $\begin{array}{l}\text { Responsible actors of } \\
\text { formulating a LPP }\end{array}$ & 14 & 3.66 & .77 & 86 & 3.59 & .68 & 14 & 3.60 & .88 & .058 & .944 \\
\hline $\begin{array}{l}\text { Attitudes of students } \\
\text { toward English }\end{array}$ & 14 & 3.84 & .64 & 86 & 4.05 & .57 & 14 & 3.91 & .71 & .951 & .389 \\
\hline
\end{tabular}

ANOVA results reported that there is no statistical influence of students' responses to the adequacy of their department policies, adequacy of their department objectives, adequacy of their department courses, determining responsible actors for language policy formulation and attitudes of students towards English due to the respondents' attitudes as presented in Table 12.

\section{Discussion of the Findings}

The aim of this study was to investigate the missions and visions of the English language departments in Jordanian universities from a linguistic planning perspective. A questionnaire was distributed to 150 students from English language departments in three public universities to target five main elements of the study. This section presents the discussion of the findings of the study along with the conclusions drawn out of these findings. It also presents the recommendations and suggestions to be taken into consideration by English language departments in Jordanian universities and related decision makers. 


\subsection{Discussion of the findings related to questions of the study}

Five questions were introduced at the outset of this study. Based on the foregoing analysis and discussion, the implication of the current study for each question can be addressed as the following:

1) To what extent are the objectives of the English language departments clear and understandable by students and appealing to the needs of the students and the market?

In light of the students' responses to the questionnaire and the general analysis of the objectives of the English departments of three universities in Jordan, it can be said that the objectives of the English departments are general and need to be reconsidered as they do not take the needs of the students or the needs of the market in consideration. Also, the objectives of the English departments are theoretical rather than practical, which makes them far beyond students' needs and aspirations.

2) To what extent are the English language departments' courses adequate to meet the needs of the students regionally and internationally?

The results of the study showed that the current courses of the English do not fully meet the current needs of the students regionally and internationally. It can be safely said that the English departments should focus more on language skills courses at the expense of other courses as the linguistic courses offer greater benefit than literature courses.

3) To what extent do the attitudes of students toward the English language affect their performance in learning the language?

The current study shows that the majority of students study English for cognitive and occupational needs. However, despite the shift of students' motivation to study English language, the psychological and social boundaries between students and learning English still exists.

4) To what extent is there an adequate language policy followed by the English departments in Jordanian universities?

It can be said that there is no adequate language policy followed by the English departments in Jordanian universities. An adequate language planning policy is needed by which the problems that face the students are taken into consideration. The general consensus about the English departments' policy in terms of their admission, examination and serving the current objectives lead to a conclusion of the necessity of formulating a unified plan and policy for the English departments in Jordan and the basis of a reasonable admission qualifications and successful examination policy are to be considered and successfully implemented.

5) Who is responsible for formulating an efficient language planning policy for the English departments at Jordanian universities?

The responsibility of formulating a language planning policy mainly lies with the English departments themselves in the very first place, followed by the dean councils and the faculty councils. However, the political, social, and economic effort cannot be neglected in the process of policy formulation. 
The Sociolinguistic Status Quo of the English Language Departments in Jordan:

A Language Planning Perspective

\section{Conclusion}

In view of the current objectives of the English departments, it can be said that these objectives are theoretical rather than practical and seem far beyond students' aspirations. These objectives are not accompanied by any specific action plan that can help realize these objectives in reality. As such, the majority of students believe that the objectives of the English departments take into consideration neither the needs of the students nor the needs of the market.

Overall, the students believe that the current English language courses do not correspond to the objectives of the departments. Moreover, the majority of students still believe that the current English courses are insufficient to graduate competent students. The course offerings of the English departments do not seem to provide students with the required outcomes that would meet their needs sufficiently. On a different note, students believe that the attitudes of students towards the English language influence their performance of learning the language. In addition to the admission exam, students believe that there should be specific qualifications for students to be accepted for the English departments. What remains an issue is the students' dissatisfaction with the policy followed by their English departments in terms of examination and evaluation, an issue that was reported in previous studies about two decades ago.

The majority of students feel that the formulation of a unified plan and policy for the English language departments can contribute to the greatest benefit. For such a language planning policy, the students feel that the English departments are the most important stakeholder and decision maker. The responsibility of the political decision-makers in formulating the language planning policy for the English departments is the least from students' perspective.

We can conclude that the language policy of the English departments needs to be reconsidered taking into account the needs of the students, the needs of the market, and the problems facing students. In particular, the objectives of the English departments must become both realistic and attainable something that should be reflected in the taught courses. The vast majority of students believe that more emphasis should be placed on language skill courses at the expense of other courses, especially literature courses. There is surely a rationale behind establishing the English departments in Jordan, but the overall adequacy of the objectives, the courses and the policy followed by these departments maybe often perceived as Teaching English for No Obvious Reason (TENOR).

\subsection{Recommendations}

In light of the overall conclusion, the following recommendations can be drawn.

1) The social and psychological attitudes of students must be taken into account as they influence students' capabilities for learning English language.

2) English language departments must be transformed into practical departments offering specialized language courses in specific fields based on students' needs instead of relying on specific published textbooks and ignoring other aspects of the English learning process.

3) The English language departments in Jordan must be dealt with as one unit so that they have a unified plan for the greatest benefit, and taking the needs of the market into consideration. 


\section{Maithalouni, Al-Abed Al-Haq, Abudalbuh}

4) The courses of the English language departments in Jordan should be transformed from General English Language Teaching (GELT) to English for Specific purposes (ESP) courses. Also, it is recommended that literature and linguistics become two different majors in B.A level with focusing on learning the language instead of focusing on literature courses.

5) A collaborative political, social, economic, educational, and academic effort is needed to formulate a successful language policy that serves the objectives of the departments, the needs of the market, and of course the needs of the students.

6) Channels of dialogue must be opened between policy makers and students through holding seminars and conferences to facilitate the knowledge of their objectives and aspirations.

7) The establishment of a language complex specialized in English, which oversees all universities, supervises the unification of university plans and their application and measuring their results theoretically and practically every five years as the following:

a) Practically, through putting students under field training in places that need English language specialization -which is not limited to (ELT)- and poll the opinions of employers in their performance,

b) Theoretically, by conducting periodic written examinations to measure the level of students' performance.

8) The implementation of the language policy is an integral part of the policy that ensures the success of the English language departments. 
The Sociolinguistic Status Quo of the English Language Departments in Jordan: A Language Planning Perspective

$$
\begin{aligned}
& \text { الوضع اللفوي الراهن في أقسام اللفة الإنجليزيّة في الجامعات الأردنيّة: } \\
& \text { الرؤى والأهداف من منظور التخطيط اللفوي } \\
& \text { ديما ميثلوني ، فواز العبد الحق ، مجدي أبو الدلبوح } \\
& \text { قسم اللفة الإنجليزية وآدابها، جامعة اليرموك، الأردن الئن الئول }
\end{aligned}
$$

تهدف هذه الدراسة إلى دراسة رؤى أقسام اللفة الإنجليزية في الجامعات الأردنية وأهدافها من منظور التخطيط اللغوي من خلال الإجابة عن أسئلة متعلقة بمدى وضوح أهداف أقسام اللفة الإنجليزية لدى الطلاب وتلبيتها لاحتياجاتهم ولاحتياجات سوق العمل، ومدى كفاية مساقات اللغة الإنجليزيّة في الجامعات الأردنية واستجابتها لاحتياجات الطلاب واحتياجات سوق العمل المحليّة والدوليّة، ومدى تأثير العلاقة الاجتماعيّة اللفويّة بين الطلاب واللفة الإنجليزيّة على مستوى أداء الطلاب، ومدى كفاية السياسة اللفويةّة المتبعة في أقسام اللفة الإنجليزية، بالإضافة إلى محاولة تحديد المسؤول عن صياغة سياسة لغوية فعّالة في أقسام اللفة الإنجليزية في الجامعات الأردنية. للإجابة عن هذه الأسئلة، تم تطوير استبانة من قبل الباحث مؤسسيًا على نموذج توليفسون (1989) مع تعديل استبانة لدراسـات سابقة أجراها الباحثون العبد الحق وصمادي (1996) وأبو دلبوح (2002). تم تطوير أسئلة الاستبانة بدقة لاستهداف العناصر الرئيسية الخمسة أعلاه، وتم توزيع الاستبانة على 150 طالباً من أقسام اللغة الإنجليزيّة في ثلاث جامعات حكوميّة في الأردن وهي: جامعة اليرموك، جامعة البلقاء التطبيقية، والجامعة الأردنية.خلصت الدراسة إلى أن رؤى أقسام اللفة الإنجليزيّة ومهامها هي نظريّة وليست عملية، وإلى عدم وجود اتساق بين الخطط ومخرجات أهداف هذه الأقسام. وتشير النتائج أيضًا إلى أن أهداف أقسام اللغة الإنجليزيّة لا تأخذ بعين الاعتبار احتياجات الطلاب واحتياجات سوق العمل ، وبالتالي فإنه يجب إعادة النظر في السياسة اللغويّة المتّبعة من أقسام اللفة الإنجليزيّة في الجامعات الأردنيّة. وخرجت الدراسة بمجموعة من التوصيات بهذا الخصوص. الكلمات المفتاحية: التخطيط اللغوي، السياسة اللغويّة، اللغويات الاجتماعيّة، أقسام اللغة الإنجليزيّة، رؤى، أهداف. 
Maithalouni, Al-Abed Al-Haq, Abudalbuh

\section{References}

AbuDalbooh, M. 2002. Developing a language planning policy model for the English Departments in Jordan. MA. Thesis, Yarmouk University, Jordan.

Abuhamdia, Zakaria A. 1984. English Departments at Arab Universities: Toward a "Planning-based Model". Language Problems and Language Planning 8 (1): 21-34.

Agheyisi, Rebecca, and Joshua A. Fishman. 1970. Language attitude studies: A brief survey of methological approaches. Anthropological Linguistics 12 (5): 137-157.

Al-Abdullah, Murad. 2017. English Language Departments: Institution for Teaching the Language or the Science of Language?. Retrieved from https://diae.net/54642/

Al-Abed Al-Haq, Fawwaz, and Oqlah Smadi. 1996. Spread of English and Westernization in Saudi Arabia. World Englishes 15 (3): 307-317.

Al-Abed Al-Haq, Fawwaz. 2016. The Arabic language in higher education from the perspective of language planning. The Thirty-Fourth Cultural Season of Jordan Academy of Arabic, the Arabic Language in Jordanian Institutions Conference. Jordan Academy of Arabic.

Al-Abed Al-Haq, Fawwaz. 2009. Islam and Language Planning in the Arab World: A Case Study in Jordan. Iranian Journal of Language Studies 3: 267-302.

Al-Abed Al-Haq, Fawwaz. 2011. Linguistic imperialism and linguistic globalization: Understanding the concepts. In Proceedings of the first international conference on literature, linguistics and translation (pp. 34-40).

Muhaisen, Mahda Said, and Fawwaz Al-Abed Al-Haq. 2007. An Investigation of the Relationship between Anxiety and Foreign Language Learning among 2nd Secondary Class Students in Second Amman Directorate of Education. International Journal of Humanities and Social Science 2 (6): 226-240.

Bader, Yousef. 1992. Curricula and Teaching Strategies in University English Departments: A Need for Change. IRAL 20 (3): 233-240.

Bugarski, Ranko. 1992. Language planning in Yugoslavia. Columbus, OH: Slavica.

Butler, Yuko Goto, and Masakazu Iino. (2004). Current Japanese Reforms in English Language Education: The 2003 “Action Plan”. Language Policy 4: 25-45.

Cooper, Robert L. 1989. Language planning and social change. Cambridge: Cambridge univ. Press.

Drabseh, Majed Mohamed Hasan. 2013. The spread of English language in Jordan. International Journal of Scientific and Research Publications 3 (9): 1-5.

Ferguson, Gibson. 2006. Language Planning and Education. Edinburgh University Press.

Fishman, Joshua A. 1971. The Impact of Nationalism on Language Planning. In Language in Sociocultural Change: Essays by Joshua A. Fishman. Stanford University Press, 1972.

Fishman, Joshua A. 1972. Language in sociocultural change: Stanford (CA): Stanford University Press.

Fishman, Joshua A., Robert L. Cooper, and Andrew W. Conrad. 1979. The Spread of English: The Sociology of English as an Additional Language. Language, Linguistic Society of America 55 (2): 463-466. 
The Sociolinguistic Status Quo of the English Language Departments in Jordan:

A Language Planning Perspective

Hamdan, Jihad. M., and Wafa A. Abu Hatab. 2009. English in the Jordanian context. World Englishes 28 (3): 394-405.

Hao, Ningning. 2018. Literature Review of Language Planning and Language Policy since 21st Century. Theory and Practice in Language Studies 8 (7): 888-892.

Harrison, William, Clifford Prator, and G. Richard Tucker. 1975. English-Language Policy Survey of Jordan. A Case Study in Language Planning. Center for Applied Linguistics.

Haugen, Einar. 1966. Linguistics and language planning. In William Bright (Ed.), Sociolinguistics: proceedings of the UCLA Sociolinguistics Conference.

Haugen, Einar. 1983. The implementation of corpus planning: theory and practice, in Cobarrubias / J.A. Fishman (eds) Progress in Language Planning: International Perspectives, Berlin: Mouton: 269290.

Hornberger, Nancy 2006. An Introduction to Language Policy: Theory and Method, in Thomas Ricento, (ed.), pp. 24-41. Blackwell.

Hutchinson, Tom, and Alan Waters. 1987. English for Specific Purposes: A Learning-centred Approach. System 16 (2): 232-237.

Ibrahim, M. H. 1984. The role of English departments in Arab Universities. In E. Dahiyyat and M. Ibrahim (eds) Papers from The First Conference on the Problems of Teaching English Language and Literature at Arab Universities. Amman: University of Jordan.

Kaplan, Richard B., Kaplan Baldauf Jr, and Robert B. Kaplan. 1997. Language planning from practice to theory. Clevedon: Multilingual Matters.

Kaplan, Richard B., and Robert B. Kaplan. 2005. Language planning and policy in Europe. Bristol: Multilingual Matters.

Khalifa, Azaddin Salem. 2012. Mission, purpose, and ambition: redefining the mission statement. Journal of Strategy and Management 5 (3): 236-251.

Kloss, Heinz. 1970. Research possibilities on group bilingualism: A report. Québec:Université Laval: Centre international de recherchesur le bilinguisme.

Mager, Robert F. 2006. Preparing Instructional Objectives. Encyclopedia of Curriculum Studies.Fearon, Palo Alto.

Mohammadi, Ebrahim Ghorban, Reza Biria, Mansour Koosha, and Azam Shahsavari. 2013. The Relationship between Foreign Language Anxiety and Language Learning Strategies among University Students. Theory and Practice in Language Studies 3 (4): 637-646.

Mansoor, Sabiha. 2005. Language planning in higher education: A case study of Pakistan. Karachi: Oxford University Press.

Nekvapil, Jiří. 2014. The history and theory of language planning. In Handbook of Research in Second Language Teaching and Learning 2: 871-887.

Nunan, David. 1988. The learner-centred curriculum. Cambridge: Cambridge University Press.

Nunan, David. 2013. Learner-centered English language education: The selected works of David Nunan. New York, NY: Routledge. 
Olshtain, Elite. 1989. Apologies across languages. In S. Blum-Kulka, J. House \& G. Kasper (Eds.), Cross-cultural pragmatics: Requests and apologies (pp.155-173). New Jersey: Ablex Publishing Corporation.

Obeidat, Marwan. 1997. Language vs. Literature in Departments of English in the Arab World. The English Teaching Forum 35 (1): 30-37.

Reagan, Timothy. 2007. Language Loyalty, Language Planning and Language Revitalization: Recent Writings and Reflections from Joshua A. Fishman edited by Hornberger, Nancy H., \& MartinPutz. The Modern Language Journal 91 (4): 716-717.

Rubin, Joan, and Bjorn H. Jernudd. 1971. Can language be planned?: Sociolinguistic theory and practice for developing nations. Honolulu: University Press of Hawaii.

Sekaran, Uma, and Roger Bougie. 2016. Research Methods For Business: A Skill Building Approach. New York, NY: John Wiley \& Sons.

Sekiwu, Denis. 2010. From Localization to Internationalization of Higher Education: Globalization and Transformation of University Education in Uganda. ERIC Clearinghouse.

Spolsky, Bernard. 2004. Language policy. New York: Cambridge University Press.

Tollefson, James. 1989. The Role of Language Planning in Second Language Acquisition. In Kennedy, Chris (ed.) Language Planning and English Language Teaching. London: Prentice-Hall.

Zughoul, Muhammad Raji, and Riad Fayez Hussein. 1985. English for higher education in the Arab world: A case study of needs analysis at Yarmouk University. The ESP Journal 4 (2): 133-152.

Zughoul, Muhammad Raji. 1983. The Unbalanced Programs of the English Departments in the Arab World. In Papers from the First Conference on the Problems of Teaching English Language and Literature at Arab Universities. Eds. Dahiyat, E. and Ibrahim, H., Amman: University of Jordan.

Zughoul, Muhammad Raji. 1985. Formulating Objectives for the English Departments in Arab Universities: Rationale and Assessment. ERIC: 1-34.

Zughoul, Muhammad Raji. 1986. English Departments in Third World Universities: Language, Linguistics, or literature? English Teaching Forum 24 (4): 10-17

Zughoul, Muhammad Raji. 1987. Restructuring the English Department in Third World Universities: Alternative Approaches for the Teaching of English Literature. IRAL 25 (3): 2-32.

Zoghoul, Muhammad Raji. 2003. Globalization and EFL/ESL Pedagogy in the Arab World. Journal of Language and Learning 1 (2): 106-146 
The Sociolinguistic Status Quo of the English Language Departments in Jordan: A Language Planning Perspective

\section{Appendix A: The Questionnaire-Arabic}

$$
\text { بسم الله الرحمن الرحيم }
$$

لقد تم وضع هذا الاستبيان حول دراسة أقسام اللفة الانجليزية في الجامعات الأردنية من منظور التخطيط اللفوي وهي للفرض العلمي فقط (رسالة الماجستير). فأرجو منكم الاجابه عن الاسئله بكل موضوعية حتى يتسنى للباحث الوصول للنتائج المرجوه, علما أنه سيتم التعامل مع الإجابات فقط ويكامل الخصوصية, شاكرين لكم حسن تعاونكم.

مكان الإقامة: يف/ مدينة

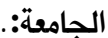

المستوى التعليمي للأم:........................ الجنس: ذكر/أنثى المستوى التعليمي للأب: .

\begin{tabular}{|c|c|c|c|c|c|c|}
\hline $\begin{array}{l}\text { أبداً } \\
\end{array}$ & لا أوافق & لا أدري & 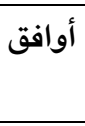 & 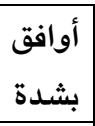 & 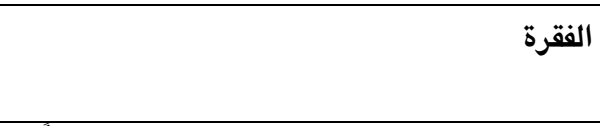 & 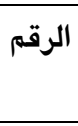 \\
\hline & & & & & واضداف قسم اللغة الإنجليزية الذي أدرس فيه حالياً & 1 \\
\hline & & & & & أهالب بعين الاعتبار. اللجافليزية الحالية تأخذ احتياجات & 2 \\
\hline & & & & & سوق العمل بعين الاعتبار. & 3 \\
\hline & & & & & قسم اللفة الانجليزية الحالية. لإعادة ليس النظر في أهداف & 4 \\
\hline & & & & & الانجليزية تخدم أهدافه الـياسة اللغوية الحالية لقسم اللغة وتحقها. & 5 \\
\hline & & & & & ساعتقد ان أهداف قسمى اللغة الإنجليزية تتوافق مع & 6 \\
\hline & & & & & ألموضوعة مسبقا للقسم الذي أدرس فيه حاليا. & 7 \\
\hline & & & & & أدرس اللغة الإنجليزية لتحقيق نفع مادي ومعنوي. & 8 \\
\hline & & & & & أدرس اللغة الإنجليزية دون هدف معين. & 9 \\
\hline & & & & & ألخارج أو التواصل الإنجليزية لأهداف معينة كالسفر الى العالم الخارجي. & 10 \\
\hline & & & & & تاؤثر خلفية الطالب الاجتماعية (كالنشأة والبيئة & 11 \\
\hline & & & & & 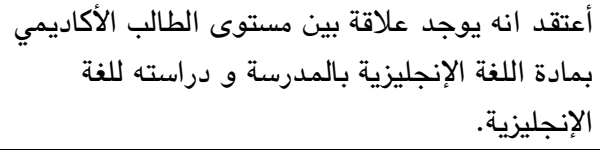 & 12 \\
\hline & & & & & أعتقد أن أهداف قسم اللفة الإنجليزية هي أهداف & 13 \\
\hline
\end{tabular}

الرجاء اختيار الاتجاه: متحرر, متحفظ, متدين 
Maithalouni, Al-Abed Al-Haq, Abudalbuh

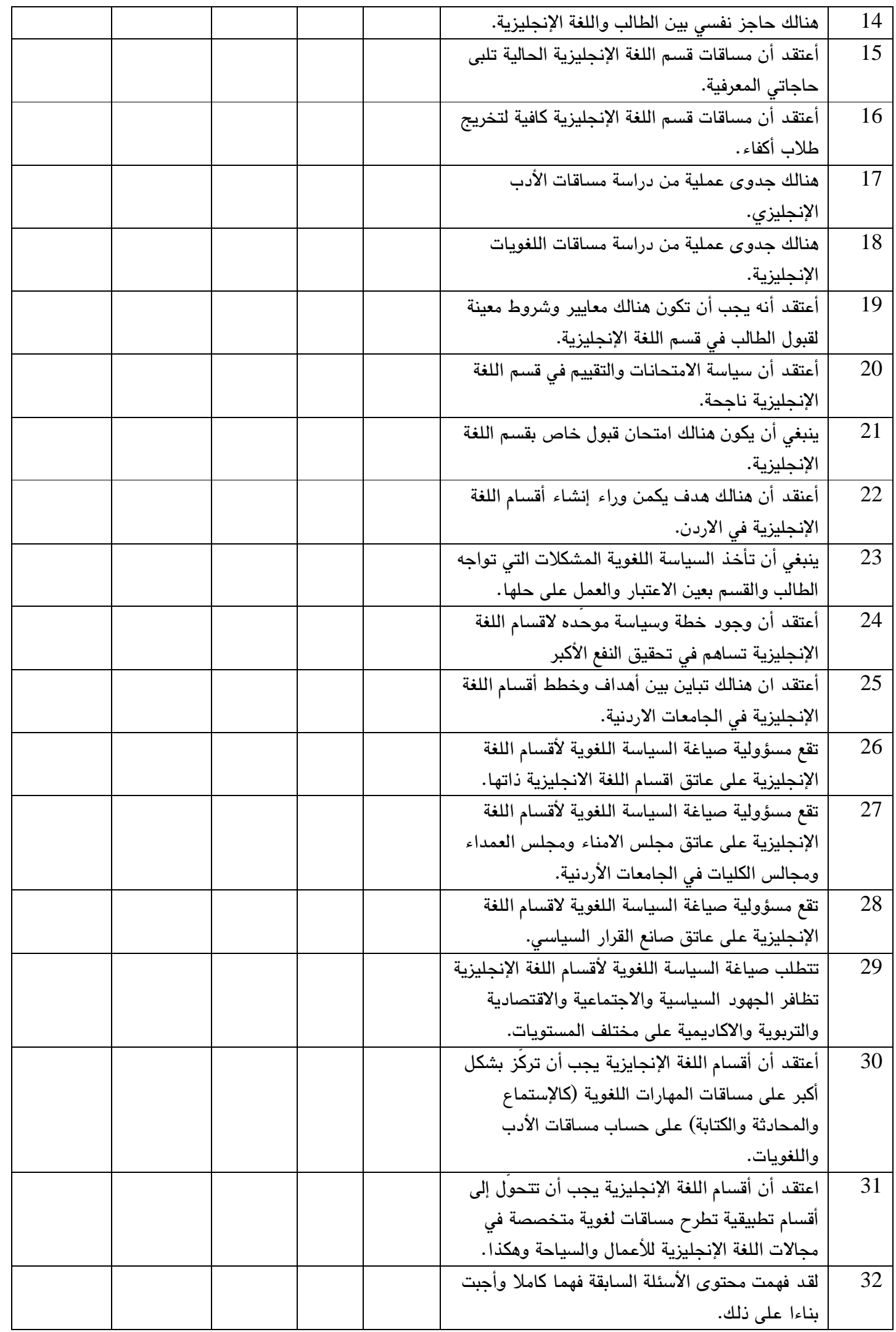


The Sociolinguistic Status Quo of the English Language Departments in Jordan:

A Language Planning Perspective

\section{Appendix B: The Questionnaire - English}

University:

Gender: Male / Female

Father's level of education:
Place of Residence: Rural / Urban

Attitude: Liberal, Conservative, Religious

Mother's level of education:

\begin{tabular}{|c|c|c|c|c|c|c|}
\hline No. & Item & SA & $\mathbf{A}$ & $\mathbf{U}$ & $\mathbf{D}$ & SD \\
\hline 1 & $\begin{array}{l}\text { The objectives of the English department in which I study } \\
\text { are clear. }\end{array}$ & & & & & \\
\hline 2 & $\begin{array}{l}\text { The objectives of the English department in which I study } \\
\text { take the needs of the students into consideration. }\end{array}$ & & & & & \\
\hline 3 & $\begin{array}{l}\text { The objectives of the English Department in which I study } \\
\text { take the needs of the market into consideration. }\end{array}$ & & & & & \\
\hline 4 & $\begin{array}{l}\text { The current English language objectives do not need } \\
\text { reconsideration. }\end{array}$ & & & & & \\
\hline 5 & $\begin{array}{l}\text { The department's current language policy serves the } \\
\text { current objectives of the department. }\end{array}$ & & & & & \\
\hline 6 & $\begin{array}{l}\text { The objectives of the English Department correspond to } \\
\text { the needs of the local market }\end{array}$ & & & & & \\
\hline 7 & $\begin{array}{l}\text { The current English language courses correspond to the } \\
\text { objectives of the department. }\end{array}$ & & & & & \\
\hline 8 & $\begin{array}{l}\text { I study English to achieve a specific physical and moral } \\
\text { goal. }\end{array}$ & & & & & \\
\hline 9 & I study English with no specific goal. & & & & & \\
\hline 10 & $\begin{array}{l}\text { I study English for specific goals like traveling abroad and } \\
\text { communicating with the outside world. }\end{array}$ & & & & & \\
\hline 11 & $\begin{array}{l}\text { The social background of the student (such like the } \\
\text { surrounding environment) affects his ability to learn } \\
\text { English. }\end{array}$ & & & & & \\
\hline 12 & $\begin{array}{l}\text { There is a relationship between the academic performance } \\
\text { of the students in the English language and their study of } \\
\text { English. }\end{array}$ & & & & & \\
\hline 13 & $\begin{array}{l}\text { The objectives of the English department are theoretical } \\
\text { and not practical. }\end{array}$ & & & & & \\
\hline 14 & $\begin{array}{l}\text { There is a psychological barrier between the student and } \\
\text { English }\end{array}$ & & & & & \\
\hline 15 & The current English courses meet my current needs. & & & & & \\
\hline 16 & $\begin{array}{l}\text { The current English courses are sufficient to graduate } \\
\text { competent students. }\end{array}$ & & & & & \\
\hline 17 & There is a practical benefit of literature courses. & & & & & \\
\hline 18 & There is a practical benefit of linguistics courses. & & & & & \\
\hline 19 & $\begin{array}{l}\text { There should be specific qualifications for students to be } \\
\text { accepted to the English department. }\end{array}$ & & & & & \\
\hline 20 & $\begin{array}{l}\text { The policy of examination in the English department is } \\
\text { successful. }\end{array}$ & & & & & \\
\hline 21 & $\begin{array}{l}\text { There should be an admission exam for the English } \\
\text { department. }\end{array}$ & & & & & \\
\hline 22 & $\begin{array}{l}\text { There is a goal behind establishing the English department } \\
\text { in Jordan. }\end{array}$ & & & & & \\
\hline 23 & $\begin{array}{l}\text { A language planning policy should take the problems that } \\
\text { face the student and the department into consideration. }\end{array}$ & & & & & \\
\hline 24 & $\begin{array}{l}\text { The existence of a unified plan and policy for the English } \\
\text { language departments contributes to the greatest benefit. }\end{array}$ & & & & & \\
\hline
\end{tabular}




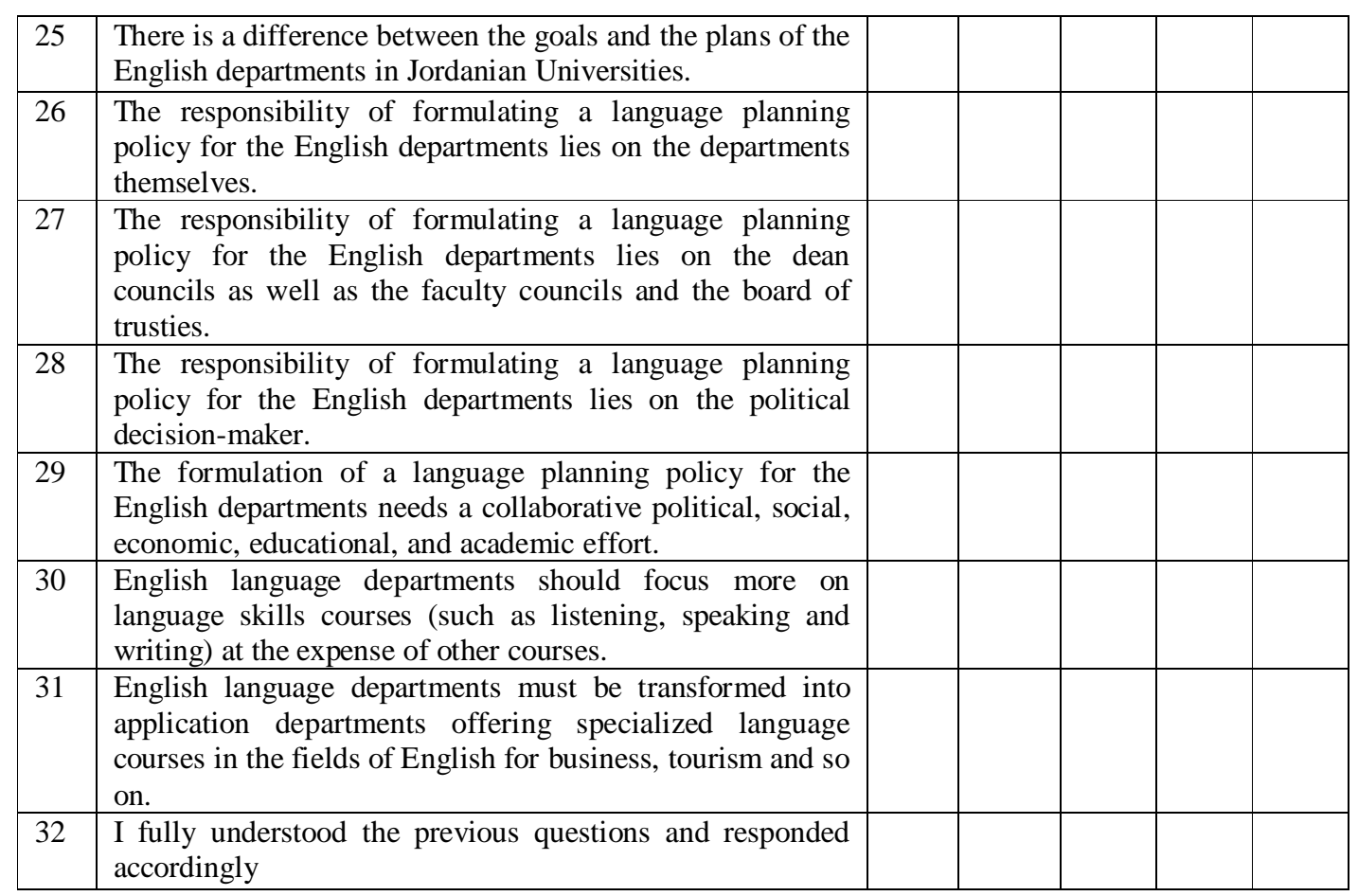

